\title{
PENCAPAIAN TUJUAN PERUSAHAAN \\ DENGAN CUSTOMER RELATIONSHIP MANAGEMENT PADA INDUSTRI JASA TELEKOMUNIKASI
}

\section{Adhi Nugroho Chandra; Angga Hardian Anugrah; Christianus Ambardi Setyoko}

\author{
Information Systems Department, School of Information Systems, Binus University \\ Jl. K.H. Syahdan No. 9, Palmerah, Jakarta Barat 11480 \\ nugroho@binus.ac.id
}

\begin{abstract}
Marketing strategies can include forms of chosen marketing communications and marketing mix strategy. A company should maintain its consumer loyalty in a long term to prevent its product being "lost" due to lack of after-sales service. Thus, a concept of customer relationship management appears to improve customer satisfaction. Furthermore, for the company, implementing a strong customer relationship management will support other business units so that the corporate goal to gain profit will be achieved, considering the function of CRM is part of marketing unit the as spearhead of the company. CRM development cannot be separated from technology. Therefore the use of CRM combined with web-based technology will result in a line of the target of a company, especially a telecommunication company, to face competition.
\end{abstract}

Keywords: marketing strategies, CRM, corporate goals, web-based technology

\begin{abstract}
ABSTRAK
Strategi pemasaran dapat mencakup bentuk komunikasi pemasaran yang dipilih maupun strategi bauran pemasaran (marketing mix). perusahaan harus dapat Menjaga kesetiaan konsumen (loyalitas pelanggan) dalam jangka waktu yang lama agar produk tidak "hilang” karena tidak adanya layanan purna jual. Hal-hal semacam itulah yang akhirnya memunculkan suatu konsep customer relationship management yang tujuan utamanya adalah untuk meningkatkan kepuasan konsumen. Selanjutnya, bagi perusahaan, menerapkan customer relationship management yang kuat akan mampu mendukung unit bisnis lainnya sehingga tujuan perusahaan untuk meningkatkan profit akan tercapai, mengingat fungsi CRM ini adalah bagian dari unit pemasaran sebagai ujung tombak perusahaan. Perkembangan CRM sendiri tidak dapat lepas dari teknologi, oleh karenanya pemanfaatan CRM yang dikombinasikan dengan teknologi berbasis web akan menghasilkan suatu garis sasaran perusahaan khususnya yang bergerak di bidang jasa telekomunikasi untuk menghadapi persaingan terutama.
\end{abstract}

Kata kunci: strategi pemasaran, CRM, tujuan perusahaan, teknologi berbasis web 


\section{PENDAHULUAN}

Tujuan perusahaan umumnya adalah memperoleh profit. Banyak cara dan strategi yang dilakukan oleh perusahaan untuk mencapai tujuan tersebut. Hampir sebagian besar dunia bisnis mengandalkan kekuatan pemasaran mereka untuk mencapai profit yang besar. Namun bukan hal mudah untuk melaksanakannya karena faktor seperti komitmen dari manajemen, karyawan, budaya perusahaan, dan kekuatan permintaan konsumen di pasar menjadi penentu tujuan perusahaan tersebut. Semakin berkembangnya persaingan mendorong perusahaan dalam industri apapun untuk menerapkan suatu terobosan atau langkah baru mencapai profit dengan lebih mudah.

Dalam beberapa kondisi, permintaan konsumen menjadi kunci tercapainya tujuan tersebut. Hal ini digambarkan seperti ini: setelah melakukan pembelian pertama pada suatu produk tertentu dengan harga terjangkau dan kualitas terjamin, konsumen akan kembali membeli produk tersebut. Dampak jangka panjang fenomena ini adalah loyalitas pelanggan terhadap produk tertentu karena telah memberikan kepuasan dan terjaminnya kualitas. Dua hal penting dalam pencapaian profit adalah bagaimana langkah awal perusahaan menentukan harga dan segmen pasarnya sehingga menembus konsumen hingga loyalitas dalam jangka waktu panjang.

Perkembangan teknologi pada akhirnya dapat mengkombinasikan tujuan perusahaan yang berbasis telekomunikasi dengan CRM melalui berbagai aplikasi berbasis web yang dapat menunjang kegiatan service, sales, dan marketing produk komunikasi untuk mendapatkan konsumen secara bebas dan mudah dengan prinsip penekanan biaya.

CRM adalah suatu pendekatan pelayanan kepada konsumen yang berfokus pada pembangunan jangka panjang dan hubungan konsumen yang berkelanjutan yang dapat memberikan nilai tambah bagi pelanggan maupun perusahaan (Turban, 2004). Sementara menurut Kalakota dan Robinson (2001), CRM adalah integrasi dari strategi penjualan, pemasaran, dan pelayanan yang terkoordinasi.

Buttle (2007) mendefinisikan CRM sebagai core business strategy yang mengintegrasikan proses internal serta fungsi-fungsi yang ada dalam perusahaan dengan jejaring eksternal untuk menciptakan dan men-deliver value (manfaat) kepada target pelanggan yang memberikan keuntungan. Dapat disimpulkan bahwa CRM merupakan strategi dan usaha untuk menjalin hubungan dengan pelanggan dan memberikan pelayanan yang memuaskan bagi pelanggan

Tujuan CRM menurut Kalakota dan Robinson (2001), yaitu: (1) menggunakan hubungan dengan pelanggan untuk meningkatkan keuntungan perusahaan; (2) menggunakan informasi untuk memberikan pelayanan yang memuaskan; (3) mendukung proses penjualan berulang kepada pelanggan.

Menurut Kalakota dan Robinson (2001) terdapat tiga tahapan CRM, yaitu: (1) mendapatkan pelanggan baru (acquire), dengan memberikan kemudahan pengaksesan informasi, inovasi baru, dan pelayanan yang menarik; (2) meningkatkan hubungan dengan pelanggan yang telah ada (enhance), melalui pemberian pelayanan yang baik terhadap pelanggannya (customer service). Penerapan cross selling atau up selling pada tahap kedua dapat meningkatkan pendapatan perusahaan dan mengurangi biaya untuk memperoleh pelanggan (reduce cost); (3) mempertahankan pelanggan (retain). Tahap ini merupakan usaha mendapatkan loyalitas pelanggan dengan mendengarkan pelanggan dan berusaha memenuhi keinginan pelanggan.

Dalam jangka waktu panjang teknologi CRM akan menyediakan suatu "pintu gerbang” bagi perusahaan mendapatkan peningkatan penjualan yang tinggi dan berujung pada peningkatan profit dari penjualan. Investasi teknologi perusahaan dalam unit CRM ini sebenarnya dapat terus dikembangkan 
ke unit bisnis lainnya untuk mengkoordinasikan berbagai fungsi sebagai satu kesatuan sehingga diperoleh integrasi tujuan perusahaan dalam kurun waktu yang panjang.

\section{METODE}

Penulisan jurnal ini menggunakan beberapa referensi sumber yang diperoleh dari internet, buku, maupun jurnal untuk memperoleh data yang akurat dan informasi yang memadai dalam kajian ini.

\section{HASIL DAN PEMBAHASAN}

\section{Hubungan CRM dengan Pencapaian Tujuan Perusahaan Jasa Telekomunikasi}

Kesatuan proses bisnis dalam perusahaan memegang peranan penting terhadap kelancaran kineja. Proses bisnis tersebut dipecah dalam beberapa unit atau departemen dalam perusahaan yang tugas dan tanggung jawabnya berbeda tetapi saling terkait dan mendukung. Terkait dengan hal itu, suatu perusahaan pastinya memiliki visi dan misi yang fungsinya sebagai pedoman bagi perusahaan menentukan strategi dan arahan dalam jangka waktu pendek maupun panjang. Jika visi terkait dengan pencapaian tujuan jangka panjang, misi diarahkan untuk pencapaian tujuan jangka pendek.

Pentingnya visi dan misi dalam perusahaan dalam hal ini perusahaan jasa telekomunikasi di Indonesia (seperti Telkom, Indosat, Excelcomindo, dsb.) selalu membuat semacam summary executive untuk menjelaskan beberapa langkah dan tindakan nyata untuk mewujudkan visi dan misi. Pada dasarnya perusahaan-perusahaan jasa telekomunikasi lebih mudah dalam menentukan strategi bisnis mereka, mengingat faktor kebutuhan terhadap komunikasi semakin meningkat seiring dengan perkembangan teknologi. Tidak bisa dipungkiri, banyak faktor eksternal yang mempengaruhi perusahaan jasa telekomunikasi menerapkan langkah pencapaian tujuan perusahaan, terutama bidang pemasaran. Pemasaran menjadi ujung tombak bagi perusahaan secara umum sebagai jalan pembuka untuk mendapatkan profit sebesar mungkin.

Tujuan perusahaan sangat bergantung pada strategi bisnis yang perusahaan jasa telekomunikasi terapkan dalam tubuh organisasinya. Butuh suatu perencanaan yang matang untuk menghasilkan suatu blueprint strategi bisnis yang memperhatikan masa mendatang, mencakup pada peluang dan resiko yang ada. Peranan pihak top manajemen dan seluruh karyawan akan sangat menunjang pembuatan suatu strategi bisnis perusahaan jasa telekomunikasi. Sebagai kuncinya, komunikasi dan teknologi yang semula terpisah namun seiring dengan perkembangan teknologi dan berbagai penelitian, kedua hal tersebut merupakan satu kesatuan sebagai suatu kebutuhan baik bagi individu, kelompok, maupun korporasi. Faktor-faktor seperti budaya, sosial, dan ekonomi sangat mempengaruhi perusahaan jasa telekomunikasi untuk menentukan segenap langkah yang diambil untuk mencapai target penjualan yang meningkat dari tahun sebelumnya sehingga didapatkan profit , atau setidaknya adalah ROI.

Seperti yang telah dijelaskan sebelumnya, bahwa tujuan perusahaan yang sifatnya pendek lebih mudah dicapai, karena banyak faktor yang dapat diprediksi dan dapat dipegang keakuratan datanya, sehingga omzet atau tingkat penjualan terhadap jasa telekomunikasi dapat terjadi secara signifikan. Untuk tujuan perusahaan yang sifatnya jangka panjang, bukan suatu langkah mudah bagi top manajemen menentukan strategi seperti apa yang akan diterapkan untuk mencapai target penjualan di masa mendatang, misalnya untuk lima tahun mendatang. Fenomena tersebut akhirnya memunculkan 
suatu pemikiran baru mengenai teknik pemasaran. Ilmu pemasaran sendiri adalah ilmu yang paling tua yang diterapkan dalam dunia industri maupun bisnis, karena pemasaran sebagai pemegang tongkat keberhasilan perusahaan mendapatkan konsumen dan pasar. Seiring dengan perubahan pandangan konsumen terhadap produk yang dikaitkan dengan gaya hidup maka muncul suatu konsep customer relationship management (CRM) yang bertujuan untuk menjaga loyalitas pelanggan terhadap produk/jasa tertentu. Bagi top manajement, pembinaan hubungan dengan kelas pelanggan khusus atau kategori konsumen berdasarkan kebutuhannya akan memudahkan dalam memberikan pelayanan yang maksimal dengan mengutamakan hubungan pemasaran. CRM dalam industri jasa telekomunikasi memegang peranan penting sebagai alat yang mampu langsung menembus kondisi konsumen, artinya bahwa konsep CRM sebagai salah satu unit bisnis yang beroperasi pada pemberian layanan tanpa batas akan membantu pihak manajemen memenuhi kebutuhan konsumennya, melalui berbagai media yang disediakan dalam CRM tersebut.

CRM yang disesuaikan dengan kebutuhan informasi dan bisnis perusahaan jasa telekomunikasi yakni dapat menyediakan akses komunikasi secara merata di seluruh Indonesia, akan melahirkan berbagai persaingan dalam industri telekomunikasi. Tidak hanya berpedoman pada strategi tujuan perusahaan, unit bisnis CRM juga menjadi penting ketika persaingan dalam industri semakin tinggi, dan kebutuhan masyarakat makin beragam. Perkembangan teknologi komunikasi menjadi penggerak utama CRM terus berlanjut dan berfokus pada pelayanan tanpa batas yang memberikan kenyamanan, dalam jangka waktu panjang. CRM terkait dengan kepuasan dan feel konsumen terhadap produk yang telah dipakai dan diketahui manfaatnya. Dengan penerapan CRM khususnya dengan media komputerisasi (misalnya CRM berbasis web) unit pemasaran dan layanan akan lebih mudah menjangkau seluruh konsumen yang jumlahnya sangat banyak. Konsumen dalam kapasitas yang besar perlu dilakukan pemeliharaan dan kontrol agar tidak terjadi kondisi "konsumen beralih" ke produk lain. Faktor penyebab utama konsumen sering beralih produk adalah kurangnya kepuasan pelayanan setelah pembelian, jadi konsumen jasa telekomunikasi merasa tidak diberikan kepuasan dalam jangka waktu lama terhadap produk telekomunikasi (bisa berupa telepon kabel, selular, bahkan akses internet).

Bagi konsumen jasa telekomunikasi, yang menjadi harapan utama bagi mereka adalah terjadinya pemeliharaan dan jaminan pelayanan setelah pembelian. Artinya bahwa pembelian mereka yang pertama bukan hanya sebagai harapan dari perusahaan jasa telekomunikasi, namun juga menjadi acuan bagi pihak perusahaan dan konsumen terhadap pelayanan yang lebih memadai. Dengan CRM yang dikontrol dengan baik, keadaan jaminan kualitas, hubungan dengan konsumen, dan pelayanan yang lebih baik akan meningkatkan penjualan perusahaan secara otomatis, mengingat pembelian terhadap produk telekomunikasi lebih banyak dipengaruhi oleh faktor kepribadian, gaya hidup, dan teknologi. Setidaknya dengan CRM yang berbasis web-misalnya akan menguatkan pondasi perusahaan-perusahaan jasa telekomunikasi menyediakan informasi yang lengkap kepada konsumen dan memberikan pelayanan yang terbaik secara total.

\section{Pergeseran Tujuan Perusahaan dalam Perspektif Teknologi}

Pada era 70 an, perusahaan-perusahaan besar di dunia masih menggunakan kertas sebagai alat pelaporan manajemen. Teknologi pada saat itu belum memadai untuk mendukung proses bisnis perusahaan. Selanjutnya pada era 80 an, banyak perusahaan mulai menyadari persaingan bisnis semakin ketat, dan teknologi adalah salah terobosan yang memungkinkan untuk memenangkan persaingan. Kemudian di era 90 an, berbagai teknologi pendukung kegiatan manajemen dan proses bisnis, mulai berkembang, sampai pada abad 20 bahwa posisi teknologi sebagai jangkar utama dalam perusahaan memenangkan persaingan. Seperti halnya dalam industri jasa telekomunikasi, bahwa persaingan produk,harga, kualitas, dan kelengkapan menjadi faktor penentu suatu perusahaan dapat bertahan di persaingan jasa telekomunikasi. Fasilitas teknologi dalam perusahaan jasa telekomunikasi 
menjadi penentu seperti apa kelancaran proses bisnisnya, bagaimana menjaga kualitas pelayanan customer, dan cara menghadapi beberapa keluhan konsumen.

Perusahaan secara umum mengharapkan profit yang didapat selalu bertambah dari waktu ke waktu, namun pada kenyataannya hal tersebut tidak mudah diterapkan, karena banyak faktor eksternal yang lebih kuat berpengaruh terhadap penjualan jasa telekomunikasi. Sejalan dengan inovasi-inovasi produk komunikasi, seperti telepon selular, PDA, maupun semacam Blackberry, akhirnya menuntut perusahaan-perusahaan jasa telekomunikasi seperti Telkom, Indosat, Excelcomindo melakukan serangkaian penyesuaian pelaksanaan strategi pemasarannya untuk mendapatkan peluang pasar yang besar. Namun, di sisi lain, faktor resesi ekonomi, dampak dari krisis global sempat melengahkan sebagian besar dunia bisnis dan industri, ditandai dengan kurs mata uang yang tidak stabil, jatuhnya perusahaan-perusahaan besar, turunnya angka investasi, dan sebagainya mengakibatkan jasa telekomunikasi mengalami penurunan. Dalam kenyataannya, meskipun terjadi fenomena semacam itu, tidak berdampak pada kebutuhan masyarakat (konsumen) terhadap produk komunikasi dan teknologi. Masyarakat lebih cenderung agresif terhadap kebutuhan komunikasi dan teknologi, karena semboyan di abad 20 ini adalah akses informasi dan kemudahan komunikasi menjadi salah satu jendela meraih dunia, artinya bahwa informasi bentuk apapun harus diperoleh dengan cepat untuk mengetahui perkembangan yang terjadi di seluruh dunia. Prospek bagus ini akhirnya menjadikan perusahaanperusahaan jasa telekomunikasi semakin gencar menetapkan serangkaian langkah pemasaran guna mencapai tujuannya memperoleh tingkat penjualan yang tinggi dan tentunya perolehan profit yang besar pula.

Bagi perusahaan profit yang besar dapat berdampak pada proses bisnis selanjutnya, tentunya ini menjadikan pondasi kuat bagi jasa telekomunikasi khususnya membuat suatu terobosan pasar telekomunikasi untuk memperluas persaingan. Tujuan perusahaan jasa telekomunikasi lebih mengacu pada peningkatan atau inovasi teknologi yang diterapkan, karena inovasi memicu konsumen untuk mencoba produk teknologi yang ditawarkan. Dalam perkembangannya memang tujuan perusahaan yang semula mencapai profit yang besar mulai bergeser ke arah pengembangan pasar yang diikuti dengan teknologi. Alasan tersebut yang akhirnya mendorong pemain besar jasa telekomunikasi di Indonesia seperti Telkom, Indosat, Excelcomindo untuk melakukan beberapa penerapan teknologi guna mendukung kegiatan hubungan dengan customernya.

Fenomena pergeseran ini ditandai dengan melebarnya pasar telekomunikasi tidak hanya sebagai penyedia fasilitas komunikasi pada alat telepon kabel, telepon selular, namun juga merambah ke dunia akses informasi seperti akses internet. Pergeseran pasar mereka ini bukan sebagai permainan, namun sebagai taktik menggapai tujuan yang lebih besar mengingat kebutuhan konsumen semakin beragam dengan perkembangan teknologi. Dunia informasi menjadi andalan bagi pemain jasa telekomunikasi untuk menyediakan jaringannya seluas mungkin, menjangkau seluruh wilayah Indonesia.

\section{Perkembangan CRM sebagai Profit dalam Jangka Waktu Panjang}

CRM dapat dikatakan sebagai profit jangka panjang perusahaan ketika perusahaan mulai memandang CRM sebagai bentuk strategi terpenting memelihara konsumen dan pasar, tanpa adanya suatu hubungan yang baik dengan konsumen, jasa atau produk tertentu dapat kehilangan citra (image) secara otomatis. Penciptaan image produk telekomunikasi di mata konsumen dapat dibangun dengan adanya penyediaan kelengkapan produk yang ditawarkan sekaligus jasa yang akan diterima oleh konsumen sebelum dan sesudah pembelian terhadap produk telekomunikasi. Konsumen Indonesia lebih mengikuti gaya hidup, preferensi, dan mutu terhadap jasa telekomunikasi, mengingat dalam penerapannya, bahwa produk telekomunikasi membutuhkan suatu kualitas pemeliharaan yang terus menerus, untuk itu kepercayaan konsumen terhadap jasa telekomunikasi yang terbaik menjadi pertimbangan utama konsumen memilih suatu jasa. Dalam waktu yang lama fenomena loyalitas 
pelanggan jasa telekomunikasi menjadi ujung tombak dan penerang bagi perusahaan jasa telekomunikasi menentukan langkah selanjutnya menerapkan taktik CRM yang lebih berkembang sehingga didapat titik puncak kepuasan dan loyalitas konsumen.

Berikut ini adalah proses CRM dalam perusahaan yang umum terjadi sebagai investasi untuk tujuan masa mendatang dari perusahaan (Gambar 1):

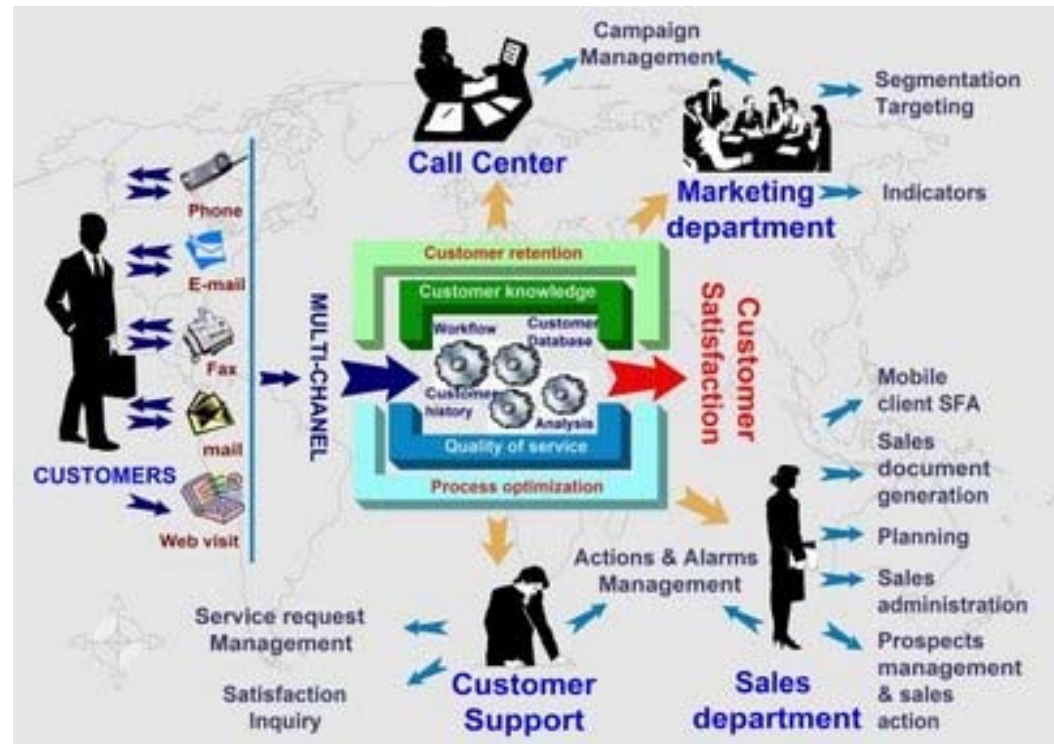

Gambar 1 Proses CRM

\section{CRM sebagai Alat Memelihara Loyalitas Pelanggan}

Pada perusahaan jasa telekomunikasi, mendapatkan konsumen yang banyak dan setia dalam jangka waktu yang lama adalah suatu pencapaian harapan yang besar, oleh karenanya diperlukan tindakan selanjutnya yang sifatnya kontinu atau berlanjut. Strategi CRM lebih menitikberatkan pada manajemen pelanggan lama - bagaimana perusahaan mengembangkan dan mempertahankan pelanggan lama (customer retention). Perusahaan jasa telekomunikasi harus menerapkan suatu CRM yang terintegrasi yang mengutamakan kemampuan perusahaan dan keseluruhan unit bisnis yang menunjang proses bisnis keseluruhan.

Strategi CRM diimplementasikan dengan harapan pengelolaan informasi dan hubungan konsumen yang lebih baik, dengan melakukan eksplorasi bagaimana meningkatkan efisiensi operasional untuk optimalisasi strategi CRM. Saat ini, bisnis telekomunikasi menggunakan sumber daya yang luas untuk memecahkan dua isu management: inefisiensi operasi yang membutuhkan peningkatan jumlah dan sumber daya pekerja dan inefisiensi praktik CRM baik gagal untuk menahan konsumen atau gagal pada pertumbuhan pendapatan. Sebagai permintaan pada stabilitas bisnis dan peningkatan pertumbuhan, nilai bisnis ditentukan melalui kombinasi dan maksimalisasi produktivitas operasional.

Banyak bisnis yang sukses saat ini, mengambil langkah untuk optimalisasi nilai prosuktif dari sumber daya internal berdasarkan pada manajemen bagi asset bisnis yang esensial membawa pada stabilitas operasional dan fokus yang baik pada pengelolaan dan pertumbuhan konsumen yang ada. Fokus pada konsumen dan hubungan bisnis akan membawa pada peningkatan pendapatan. Manajemen yang tidak efektif akan mengurangi nilai proporsi CRM dan memimpin diskusi mengenai valliditas teknologi CRM. Manajemen organisasi akan membawa dan menentukan nilai strategi CRM dan 
kesuksesannya. Lebih spesifik bisnis memfokuskan perhatiannya pada bagaimana tenaga kerja yang berpengetahuan berinteraksi dengan konsumen melalui banyak cara dan mengidentifikasi metode yang tepat untuk meningkatkan efisiensi.

Ketika konsumen berbicara dengan agen pada contact center, mereka mengekspektasikan bahwa agen tidak hanya mempunyai informasi yang sudah tersedia tetapi juga menangani permintaan secara efisien. Solusi dari kegagalan CRM adalah meningkatkan pengelolaan pelanggan melalui penciptaan lingkungan bagi pelanggan. Berdasarkan pandangan CRM, pekerja yang berinteraksi dengan konsumen akan lebih kaya dengan informasi yang tersedia. Pekerja ini akan siap mempengaruhi pelayanan dan kepuasan konsumen, membangun loyalitas konsumen yang lebih tinggi dan meningkatkan customer retention. Chanel bisnis konsumen harus dibangun yang mendemonstrasikan bahwa mereka dapat menerima keuntungan operasional yang akan membawa pada pertumbuhan perusahaan yang lebih baik dan profitabilitas yang lebih tinggi. Menjalankan bisnis secara efektif sangat penting bagi kesuksesan strategi manajemen strategis. Integrasi desktop memungkinkan hubungan konsumen untuk memenuhi tantangan menciptakan peningkatan kepuasan dan loyalitas konsumen sambil meningkatkan produktifitas pekerja dan mengurangi semua biaya operasional. Integrasi desktop juga memungkinkan peningkatan pendapatan. Integrasi desktop juga merupakan asset bisnis dan nilai yang tidak hanya meningkatkan pengalaman konsumen tetapi juga menambahkan pendapatan perusahaan.

Pada penjelasan di atas, bahwa CRM mampu memelihara loyalitas pelanggan, ini mengindikasikan bahwa proses untuk pemeliharaan ini butuh suatu perencanaan teknologi yang tinggi untuk menghasilkan suatu sistem CRM terintegrasi yang mampu memberikan kecepatan perolehan informasi dan data. Dilihat dari Gambar 2, di bawah ini, penyampaian informasi penting kepada konsumen dapat dilakukan dengan memberikan informasi yang akurat, cepat, dan update.

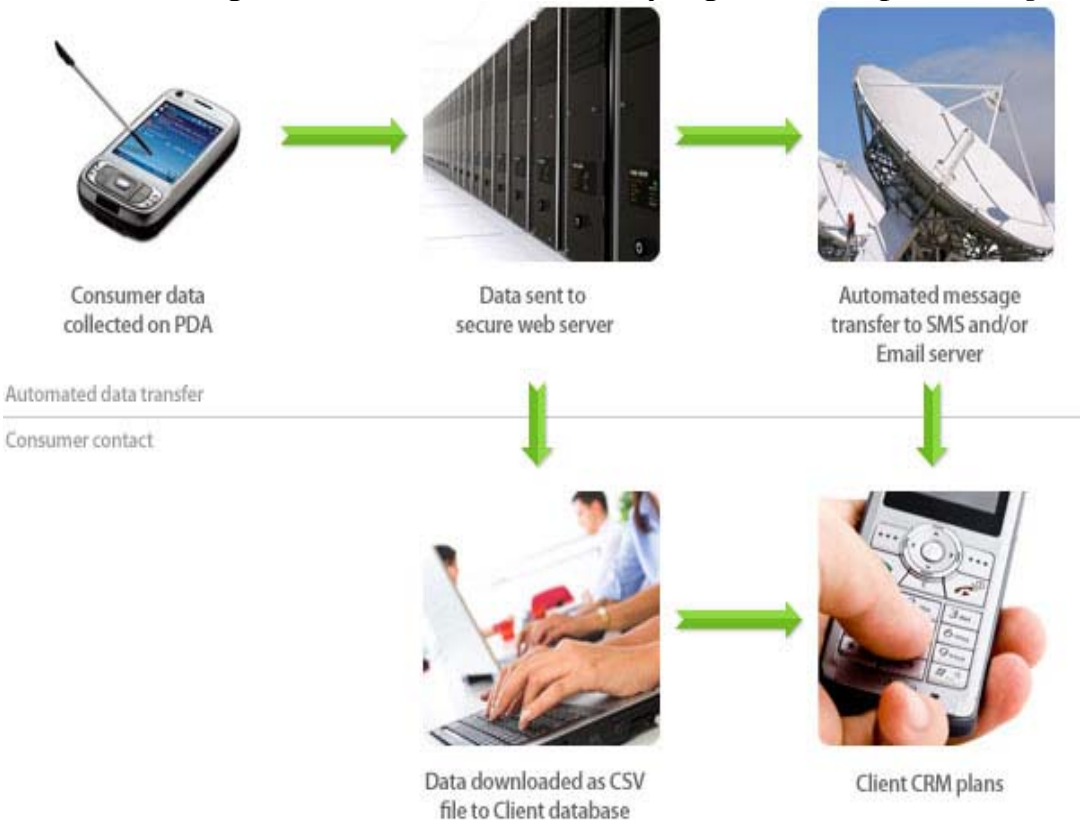

Gambar 2 Proses penyampaian informasi kepada konsumen dengan aplikasi CRM (email alert)

\section{CRM dalam Perspektif Bisnis Telekomunikasi}

Di Indonesia pemain besar jasa telekomunikasi adalah perusahaan yang memiliki jaringan kuat terhadap fasilitas komunikasi di Indonesia, seperti PT Telekomunikasi Indonesia, PT Indosat, PT Excelcomindo Pratama. Ketiga perusahaan besar ini bersaing dalam bidikan pasar konsumen. 
Persaingan yang terjadi seringkali terletak pada tarif telepon yang diberikan kepada konsumen. Namun bagi pandangan konsumen Indonesia, pembelian pertama harus diikuti dengan program pelayanan yang memadai dalam waktu yang lama dan terus menerus. Masing-masing pihak di atas menerapkan CRM dalam bentuk berbeda, karena dalam kenyataannya CRM adalah sebuah strategi yang terintegrasi dengan teknologi dan untuk mencapai integritas tersebut dibutuhkan suatu aplikasi CRM yang memadai dan mampu mendapat tanggapan atau respon yang baik dari konsumen. Selanjutnya dalam perjalanannya nanti, CRM ini dapat memberikan suatu kontribusi bagi perusahaan khusunya mengenai pendapat, harapan, dan keluhan dari pelanggan yang pada akhirnya dapat memberikan gambaran bentuk pelayanan seperti apa yang mungkin harus diciptakan oleh ketiga perusahaan jasa telekomunikasi tersebut.

PT Telekomunikasi Indonesia membangun hubungan secara online dengan pelanggan dalam bentuk myTelkom (website pribadi pelanggan), e-Complain untuk keluhan pelanggan, e-billing untuk penagihan dan beragam aplikasi lain yang dapat diterapkan disisi CRM dalam konteks sistem informasi bisnis perusahaan. Manfaat yang ingin dirasakan melalui penerapan CRM berbasis online di antaranya adalah adanya kemampuan Telkom untuk dapat memahami kebutuhan setiap pelanggan baik yang bersifat pribadi maupun korporasi sehingga diharapkan akan meningkatkan kualitas pelayanan melalui penetapan prioritas layanan yang berbeda untuk setiap pelanggan. Melalui portal CRM-nya, yaitu Telkom e-service, Telkom berusaha menempatkan diri sebagai perusahaan yang dapat memberikan layanan penuh kepada konsumennya tanpa dibatasi ruang dan waktu. Diharapkan dengan Telkom e-service (Gambar 3), konsumen Telkom dapat memperoleh kebutuhan pelayanannya dengan maksimal dan mendapatkan keuntungan dari segi waktu, biaya, dan tenaga.

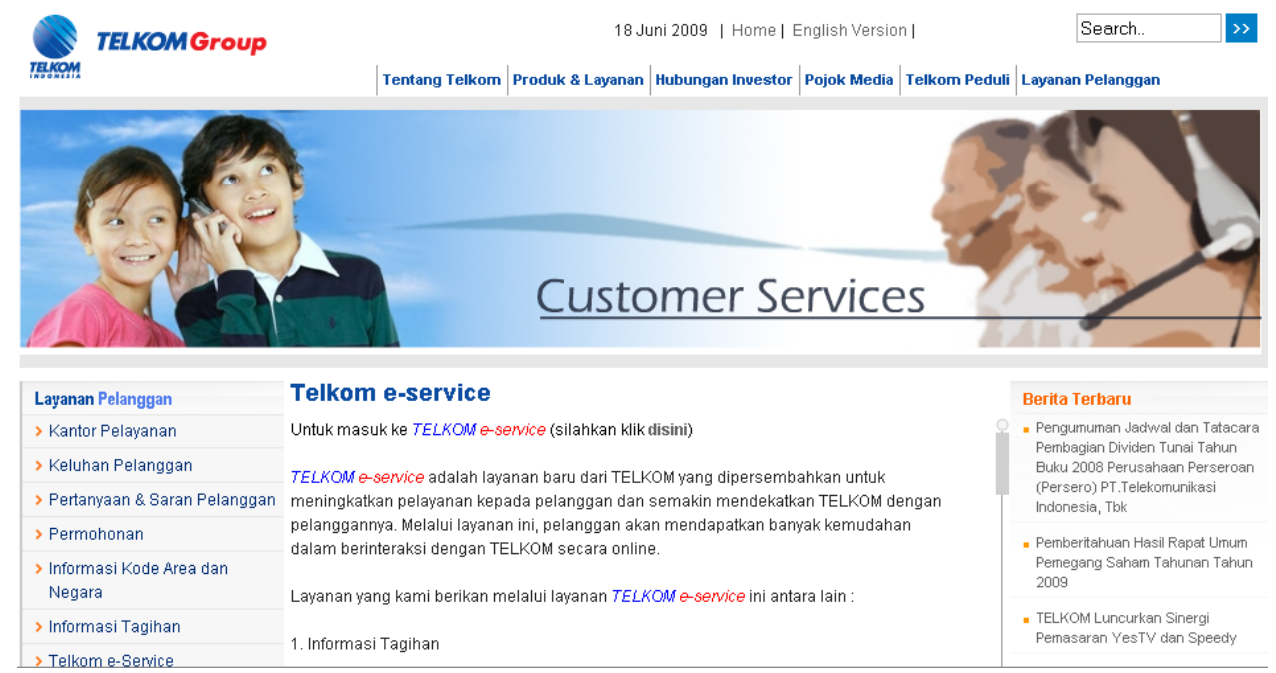

Gambar 3 Portal CRM pada PT Telekomunikasi Indonesia (Telkom e-service)

Pada PT Indosat, program Peningkatan Infrastruktur Pelayanan Pelanggan dilakukan melalui pengembangan Interactive Voice Response, peningkatan Accessibility Contact Center Pra Bayar, pengembangan dan implementasi Integrated CRM Application atau I-Care dan standarisasi tampilan baru Galeri Indosat. Pada website CRM yang disediakan dalam situs resmi PT Indosat (Gambar 4), konsumen Indosat diberikan kemudahan untuk mendapatkan informasi dan menyampaikan keluhannya jika terjadi ketidaklancaran berkomunikasi atau mengalami gangguan jaringan. Website ini dilengkapi dengan berbagai fitur yang mendukung hubungan konsumen dengan pihak Indosat. 


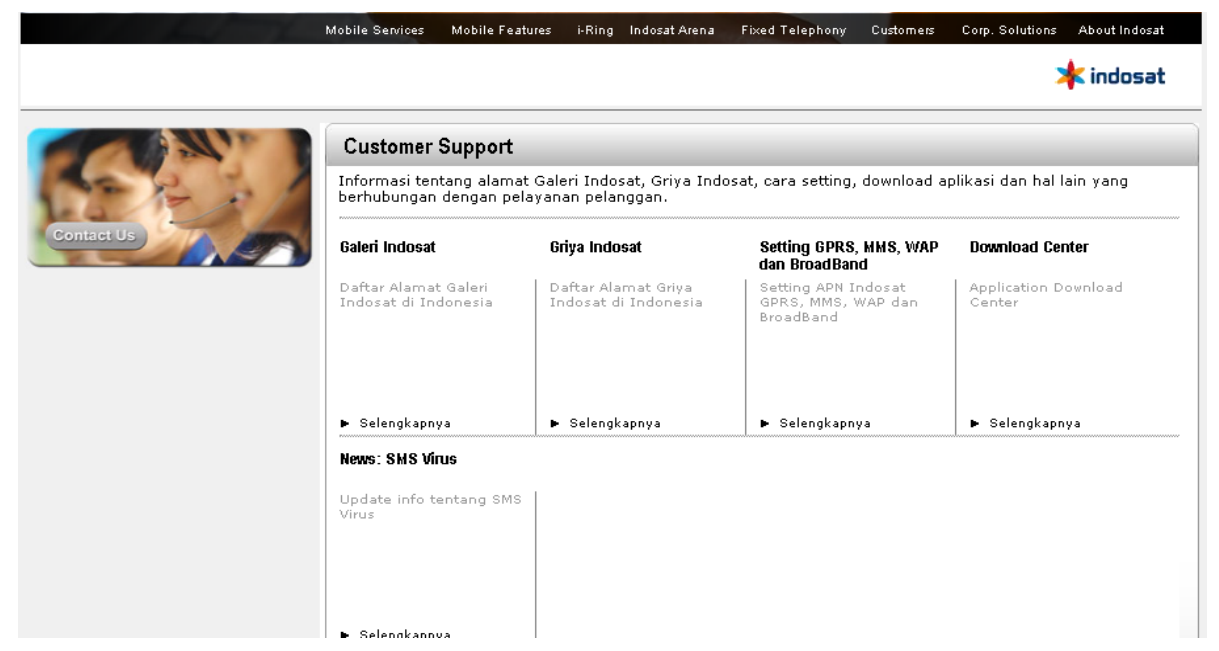

Gambar 4 Website customer support PT Indosat

Untuk mewujudkan visinya sebagai operator seluler terbesar di tanah Air, PT Excelcomindo Pratama Tbk. (XL) menempatkan unit Layanan Pelanggan atau XL Contact Management sebagai tulang punggung dalam menghadirkan layanan berkualitas. Dengan terus memaksimalkan unit layanan yang didukung Integrated CRM (Customer Relationship Management) System ini, XL sekaligus siap menyongsong penerapan Standar Kualitas Layanan. Tindakan tesebut seiring peningkatan jumlah pelanggan, maka XL juga terus meningkatkan kualitas layanan yang disesuaikan dengan kebutuhan dan mobilitas pelanggan, sehingga perlu menerapkan Integrated CRM System sebagai salah satu keunggulan perusahaan yang kompetitif. XL Contact Management memberikan layanan bagi 26 juta pelanggan melalui XL Contact Center (untuk layanan telepon dan surat menyurat elektronik serta faksimili) dan XL Center (untuk layanan walk-in atau kunjungan langsung). XL juga menyediakan layanan Video Contact Center berbasis 3G yang memungkinkan pelanggan bertatap muka dengan petugas Layanan Pelanggan. Layanan ini merupakan layanan Video Contact Center Pertama di Indonesia. Di sisi sumberdaya manusia, XL Contact Center 817 diperkuat oleh tim yang multi skills untuk memberikan solusi komunikasi yang beragam. Bahkan, untuk keluhan yang spesifik, misalnya menyangkut data komunikasi dan gadget, didukung dengan tim khusus yang akan membantu memecahkan masalah menyangkut gadget. Salah satu solusi komunikasi yang diberikan XL adalah solusi telekomunikasi korporat berbasis GSM dan Non GSM yang diberikan oleh XL Business Solutions. Solusi ini sangat beragam mulai dari sirkit sewa (leased line), broadband, IP (internet protocol), internet HSDPA, BlackBerry, hingga penyediaan PABX berbasis GSM dan telepon untuk pelanggan korporat. XL Contact Management didukung oleh 356 XL Center yang tersebar di seluruh Indonesia dan XL Contact Center yang melayani pelanggan XL selama 24 jam dan 7 hari seminggu. Sebagai upaya meningkatkan kepuasan pelanggan, XL Contact Center telah menambah titik layanan di beberapa lokasi, sehingga memiliki kemampuan load balancing dan disaster recovery system. Website milik PT Excelcomindo Pratama di bawah ini (Gambar 5) disediakan untuk memberikan pelayanan kepada pelanggan produk Excelcomindo, di mana pelanggan dapat menggunakan email atau call center pada Excelcomindo. Dalam pelayanan ini, pihak Excelcomindo mengelompokkan konsumen berdasarkan dari produk yang digunakan oleh konsumen,terdiri dari produk GSM dan Non GSM. Tujuan dari pengelompokkan ini merupakan langkah bagus untuk mencapai target dengan benar sehingga optimalisasi pelayanan dapat terpenuhi. 

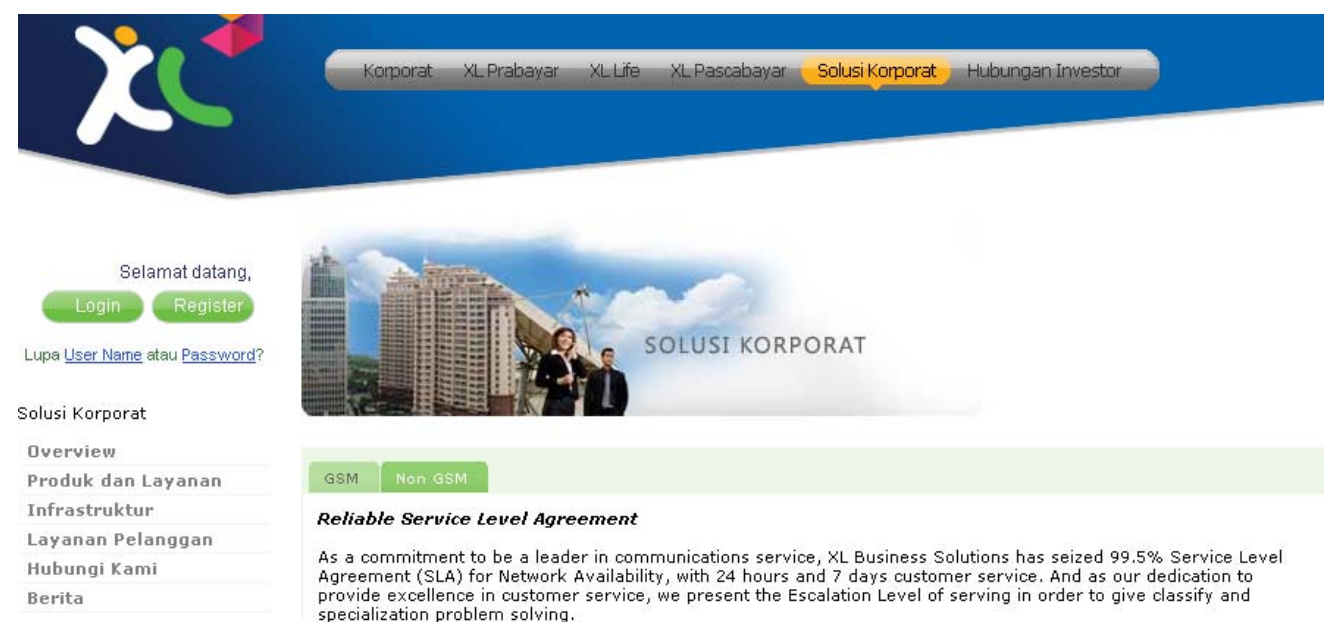

As a commitment to be a leader in communications service, XL Business Solutions has seized $99.5 \%$ Service Lev
Agreement (SLA) for Network Availability, with 24 hours and 7 days customer service. And as our dedication to provide excellence in customer service, we present the Escalation Level of serving in order to give classify and specialization problem solving.

Feel free to call our corporate customer service officer anytime at:

817 (from XL number) or 021 - 57959817 / 021 - 57959556 (from other) or email: corpacc@xl.co.id

Gambar 5 Portal pelayanan PT Excelcomindo Pratama

\section{Langkah Perusahaan Jasa Telekomunikasi dalam Menerapkan CRM}

Piranti CRM hanya mampu mendorong dan memperkuat proses penjualan dan pelayanan pelanggan. Tetapi, jika orang-orang di bagian penjualan dan pelayanan tidak mau menggunakan piranti itu, maka perusahaan hanya akan menghabiskan uang tanpa memperoleh hasil optimal. Para praktisi yang sangat berpengalaman dalam penerapan CRM menyarankan agar setiap orang yang terkait dalam CRM ini hendaknya dilibatkan sejak awal proyek itu dijalankan. Berikan mereka tanggung jawab, sehingga hal itu akan memupuk keterlibatannya dalam proyek yang dijalankan. Di sisi lain, dengarkan pandangan dan pendapat orang-orang yang ada di depan, yang menjual dan melayani pelanggan, utamanya untuk menemukan proses-proses tersembunyi yang sebenarnya menjadi kekuatan perusahaan. Diperlukan suatu persiapan yang baik untuk menghadapi perubahan dalam lingkungan kerja mereka, terutama karena diterapkannya CRM. Yakinkan mereka bahwa perubahan itu justru akan memberikan sesuatu yang lebih baik, baik bagi karyawan maupun perusahaan.

Untuk membangun strategi CRM yang efektif, ada empat langkah penting yang harus dilakukan yaitu: (1) mengidentifikasi karakteristik dari setiap pelanggan; (2) membuat model dari nilai setiap segmen pelanggan; (3) menciptakan strategi yang proaktif dan rencana pelaksanannya atau metoda bisnisnya, yang dapat menjawab kebutuhan pelanggan, dimulai dengan segmen pelanggan yang paling potensial; (4) mendesain ulang struktur perusahaan sepanjang diperlukan, proses kerja, teknologi dan sistem penghargaan untuk pelanggan dalam rangka mengimplementasikan strategi peningkatan hubungan dengan pelanggan.

Setelah menerapkan empat langkah di atas, perusahaan jasa telekomunikasi dapat mengintegrasikan komponen CRM secara keseluruhan, yaitu komponen marketing, sales, dan service (Gambar 6). Setiap komponen mengharuskan perusahaan jasa telekomunikasi menerapkan tindakan. Umumnya service menjadi komponen terpenting dalam memajukan hubungan dengan customer karena sifat dari industri jasa adalah pelayanan yang berkelanjutan dan ketersediaan fasilitas jaringan mampu mencapai minat konsumen. 


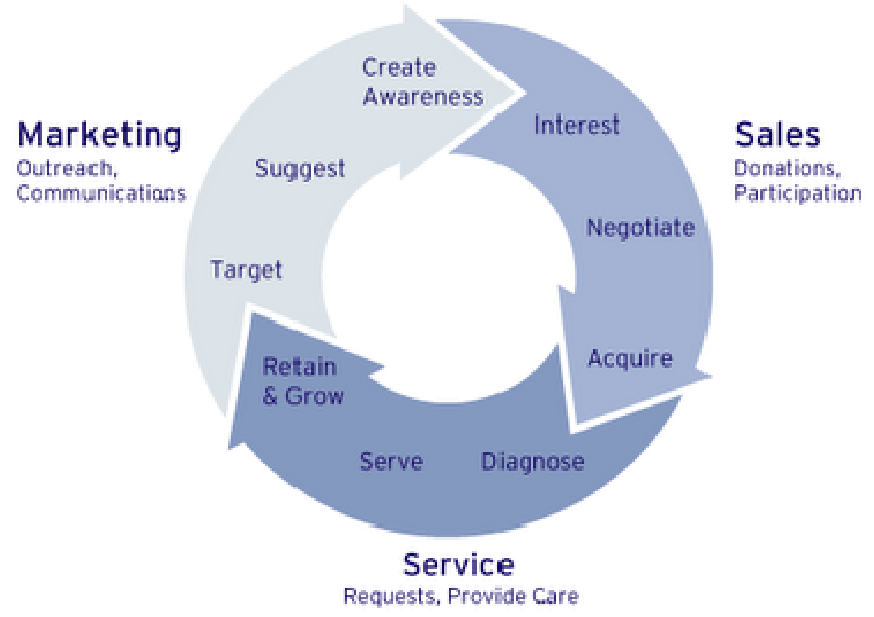

Gambar 6 Beberapa komponen dalam CRM terintegrasi dalam perusahaan

\section{PENUTUP}

Berdasarkan kajian di atas, dapat ditarik kesimpulan mengenai customer relationship management dalam industri jasa telekomunikasi: (1) Dengan adanya sistem CRM (Customer Relationship Management), diharapkan para pelaku bisnis dapat mengetahui bagaimana langkah langkah atau cara cara melayani konsumen, agar konsumen merasa puas sehingga keuntungan yang diperoleh semakin meningkat. Apabila konsumen merasa puas dengan pelayanan perusahaan, secara otomatis konsumen tersebut akan membeli lagi, atau bahkan menjadi pelanggan tetap bagi bisnis telekomunikasi, mengingat telekomunikasi menjadi kebutuhan primer bagi masyarakat; (2) untuk mengembangkan dan menerapkan CRM diperlukan rangkaian proses yang memungkinkan dilakukannya analisis pelanggan, sehingga perusahaan dapat mengenali pelanggan secara individual. Perusahaan tahu pelanggan mana yang berpotensi memberikan keuntungan besar dan mana yang merugikan. Treatment macam apa yang harus diberikan ke setiap pelanggan secara berbeda sehingga value yang diberikan lebih baik dari pesaing; (3) dalam industri jasa telekomunikasi di Indonesia, pemain besar dalam industri tersebut harus mampu menyeimbangkan kekuatan strategi pemasaran CRM dengan kemajuan teknologi untuk menunjang kelancaran kegiatan komunikasi konsumen Indonesia; (4) CRM pada dasarnya adalah sebuah strategi pemasaran yang berkembang akibat perkembangan teknologi, sehingga sifatnya adalah lebih besar perananannya dalam memelihara konsumen yang telah lama menjadi pelanggan, artinya bahwa CRM yang paling mudah dilakukan adalah memelihara konsumen yang telah ada.

\section{DAFTAR PUSTAKA}

Buttle, Francis. (2007). Customer Relationship Management (Manajemen Hubungan Pelanggan): Concept and Tools. Malang: Bayumedia Publishing.

Kalakota, Ravi., and Marcia Robinson. (2001). E-Business 2.0: Roadmap for Success. Boston: Addison-Wesley.

Turban, E., King, D., Viehland, D., Jae Lee. (2004). Electronic Commerce: A Managerial Perspective. New Jersey: Pearson Education. 